Meta

Journal des traducteurs

Translators' Journal

\title{
The Term Dharma: A study in cross-cultural semantics
}

\section{Arvind Sharma}

Volume 39, numéro 2, juin 1994

La traduction vue de l'extérieur - Translation: a view from the outside

URI : https://id.erudit.org/iderudit/004125ar

DOI : https://doi.org/10.7202/004125ar

Aller au sommaire du numéro

Éditeur(s)

Les Presses de l'Université de Montréal

ISSN

0026-0452 (imprimé)

1492-1421 (numérique)

Découvrir la revue

Citer cet article

Sharma, A. (1994). The Term Dharma: A study in cross-cultural semantics. Meta, 39(2), 307-312. https://doi.org/10.7202/004125ar

\section{Résumé de l'article}

Dans les langues indiennes, il n'existe pas de terme qui corresponde parfaitement au mot religion tel qu'utilisé dans les langues occidentales mais, plutôt, toute une série de termes qui peuvent servir, en traduction, à exprimer différentes connotations. Cet article étudie les implications culturelles et sémantiques de la traduction de religion par dharma en langues indiennes. 


\title{
THE TERM DHARMA: A STUDY IN CROSS-CULTURAL SEMANTICS
}

ARVIND SHARMA

McGill University, Montreal, Canada

\begin{abstract}
Résumé
Dans les langues indiennes, il n'existe pas de terme qui corresponde parfaitement au mot religion tel qu' utilisé dans les langues occidentales mais, plutôt, toute une série de termes qui peuvent servir, en traduction, à exprimer différentes connotations. Cet article étudie les implications culturelles et sémantiques de la traduction de religion par dharma en langues indiennes.
\end{abstract}

If one is asked to provide a synonym for the English word religion from among the Indian languages, the most common word likely to be offered is dharma from among the various possible terms. Klaus K. Klostermaier writes:

If we try to find an Indian synonym for the term religion - admittedly difficult to define even within the Western tradition! - we have to choose from a variety of terms, none of which coincides precisely with our word. The most common and most general term is dharma, usually translated as 'religion' (1989: 46).

Yet that very response, while it may provide an answer at the verbal level, constitutes the core of the problem we wish to address at the cultural level. For according to the eminent Indologist Daniel H. H. Ingalls "Ancient India ... had no word for religion" (Smith 1963: 248-249). This has led the equally eminent historian of religion, Wilfred Cantwell Smith to suggest that the "modern Hindi dharam is developing a meaning of the English term 'religion' that its classical Sanskrit counterpart did not have" (1963: 59).

This opens the floodgates of the issue we wish to address in this paper, namely, the issue of verbal versus semantic equivalence in the context of cross-cultural translations, and the cultural implications of insisting on lexical equivalence.

While it may be true to say that Ancient India had no word for religion, it does not thereby follow that it did not have a word to convey the shade of meaning which was meant to be conveyed by the use of the world religion in English in a given context. It could even be argued that perhaps all the different shades of meaning conveyed by the world religion in English could be conveyed by different words in Sanskrit or modern Indian languages. Thus we have a situation in which although the word itself perhaps cannot be translated, its various meanings nevertheless can be translated. Yet the urge to use a specific word to translate another specific word is so pervasive in the enterprise of crosscultural translation that not only is this fact lost sight of, the urge to employ word-for-word translations sometimes leads to not merely curious but sometimes serious consequences.

The urge to favour word-for-word or literal translations is not necessarily the result of inertia or lack of insight. The case on hand, for instance, is convoluted by the fact that strong linguistic and even philosophical reasons may lie at the root of it. The English word religion is originally from the Latin religio, of which three etymologies have been offered, sometimes referred to in shorthand as the leg, the lig and lig-etymologies. According to the leg explanation, the word is derived from the root legere, "to gather, to study, to 
read", and may pertain to what is piously pursued. According to the lig explanation, the word is derived from the root ligäre, "to bind", and thus indicates the union of man with god or the communion of followers. According to the lig-explanation, as that verb means "to pay attention, to give care", it indicates the solemnity religion represents (204-205).

The use of the word religion to translate dharma or vice versa has evoked a whole range of emotions from strident opposition to lukewarm support (Chaturvedi 1990) but even those who use them as equivalents seem to hold their nose while doing so. However, an etymological investigation of the term dharma reveals that at least its sense may not be as far removed from the word religion according to its lig explanation as might appear at first sight. The word dharma is derived from the root dhr, "to support, to uphold", and according to one primary semantic configuration "it is defined as that which sustains society" (Mahadevan 1937: 166; Basham: 137). This sense is not far removed from the explanation of the word religion as that which binds a community together.

Moreover, the word religion itself is not free from ambiguity. The comparative study of religion has done much to expose this ambiguity, and the consequent difficulties have multiplied to such an extent that some have recommended the use of the word be discontinued (Smith: 156), while others have had to take recourse to Wittgensteinian strategies to justify using it. John Hick writes (1983: 2-3):

Perhaps a more realistic view is that the word 'religion' does not have a single correct meaning but that the many different phenomena subsumed under it are related in the way that the philosopher Ludwig Wittgenstein has characterized as family resemblance. His own example was the word 'game'. You cannot define a game as being played for pleasure (for some are played for profit), or as being competitive (for some are solo performances), or as requiring skill (for some depend on chance), or indeed it would seem by any single feature. Yet all these different kinds of game overlap in character with some other kinds, which in turn overlap in different ways with yet other kinds, so that the whole ramifying collection hangs together in a complex network of similarities and differences which Wittgenstein likened to the resemblances and differences appearing within a family. We may apply Wittgenstein's idea to the word 'religion'. Perhaps there is no onc characteristic of everything that can be called a religion, but rather there is a set of 'family resemblances'. In much religion there is the worship of a God or gods; but in Theravada Buddhism, for example, there is not. Again, religion often makes for social cohesion; yet in some strands it is aptly characterized as 'what man does with his solitariness' (A. N. Whitehead). Again, religion often makes for the inner harmony of the individual; yet some of the greatest religious innovators seemed to their contemporaries to be unbalanced and even insane. The family resemblances model allows for such differences.

If, however, one surveyed the gamut of meanings covered by the word dharma in Hinduism, and specially in Indian culture, might not one face a similar dilemma? Klostermaier observes that dharma

has been given diverse meanings in various Indian schools of thought. At one end of the spectrum, we have the Buddhist interpretation, in which dharma is merely a logical element of a proposition. Generally, howcver, it is used with reference to religion in the specific sense of socio-ethical laws and obligations (1989: 47).

Even in the Buddhist sense it possesses a host of meanings:

The word dharma is employed in Buddhism a little differently from its use in Hinduism, and is strictly untranslatable in English. One leading authority has translated it as 'the Norm'; in our extracts it is translated 'the doctrine', 'Righteousness', or 'The Law of Righteousness' according to context. The term dharma in Buddhism has also other connotations. Phenomena in general are dharmas, as are the qualities and characteristics of phenomena. Thus the 
Buddha's last words might be translated: 'Growing old is the dharma of all composite things' (Basham 1958: 96).

Its usage in Hinduism sometimes overlaps with the Buddhist and sometimes diverges from it, but on the whole it possesses its own distinct constellation of meanings within Hinduism and the apparent variation in meaning of the word merely in the Hindu context could well cause consternation. The eminent jurist P. V. Kane, to cite only one instance, commences his section entitled "Meaning of Dharma in his magnum opus" - the fivevolume History of Dharmaśästra with the following comment (1968: 1):

Dharma is one of those Sanskrit words that defy all attempts at an exact rendering in English or any other tongue. That word has passed through several vicissitudes. The dictionaries set out various meanings of Dharma such as 'ordinance, usage, duty, right justice, morality, virtue, religion, good words, function or characteristic'. Dharma is also personified as a deity, as in the well-known verse..."

It is now time to draw attention to the fact that the use of the word dharma for religion and vice versa possesses not merely nominal but also cultural implications. The depth to which the concepts represented by the word dharma have percolated in the Hindu psyche cannot be plumbed by the English word religion. This becomes evident from the following anecdote narrated by S. Radhakrishnan:

It is related of an Indian Christian convert who attended the church on Sunday and the Kāli temple on Friday, that when the missionary gentleman asked him whether he was not a Christian, he replied, 'Yes, I am, but does it mean that I have changed my religion?' (1927: 39)

The significance of the remark can only be grasped in all its fullness if the word religion in the above remark is understood as a translation of dharma.

The plot thickens when one asks the question: what word did the Hindus use for their own religion? Kees Bolle, who had to render the word dharma often into English in the course of its numerous occurrences in the Bhagavadgita when he translated that text, remarks (1979: 243):

Dharma is a transparent term in most instances. Translators have understood it as 'duty', 'law', 'traditional rules', '(right) tradition', and 'religion', and I have not deviated from these specific interpretations. 'Hinduism' is the name outsiders assigned to the entire collection of Indian religious customs and institutions, and it is interesting to recall again that from within Hinduism the only name that qualifies to sum up this collection is sanatanadharma, the eternal dharma.

The rendering of sanätanadharma as eternal dharma or eternal religion (Mahadevan 1971: 12) is not unjustified but is not without problems given the cultural context in which it appeared. The English translation naturally came in vogue in the nineteenth century when, to outside observers, Hinduism presented the image of an unchanging and therefore eternal religion. And this perception, fortified by the English translation, also led many Hindus into believing in its eternal, that is to say permanent, which is to further say unchanging, nature. Benjamin Walker notes (1968-I: 445):

Hindus themselves like to refer descriptively to their religion as sanātana, 'eternal' or 'ancient'. In this context the term is of very recent usage, barely half a century old, and under cover of this appellation many misguided patriots resisted with much learned labour the changes that were so rapidly transforming their religion, since it meant surrendering the 'ancient' ways.

Here we have an instance of a possible indigenous misunderstanding being reinforced by an English translation which emphasizes the static nature of the tradition, thereby 
making it resistant to change. In drawing attention to this phenomenon, however, Walker invents a false plot and further thickens it by suggesting that in this context the term is of very recent usage', when such usage can be traced back to Khanapur Plates of Mādhavavarman involving a land-grant in Returaka (modern Retrem) in Satārā District of Mahārăștra State which are assigned to the 6th century C.E. (Kane V-II: 1629).

The central issue is articulated lucidly by Kees Bolle as follows (251):

The problem is: How are we to do justice to a religious tradition that is dynamic in structure with the help of an ideology that we have inherited which is comparatively static, conceptualistic, and disinclined to see anything dynamic in an archaic culture?

The translation of sanātana as eternal falls right into that pit and only serves to intensify this problem. Yet how strong a grip habitual modes of thought and therefore translation have on us can be illustrated from passages from Bolle's own translation of the Bhagavadgitä. The relevant passage consists of verses $40-43$ of the first chapter of the Gĩtā, which are reproduced below in transliteration as well as translation (1979: 12-13):
40. kulakșaye pranaśyanti kuladharmāh sanātanàh dharme naste kulam krtsnam adharmo 'bhibhavaty uta
40. With the disruption of the family, the eternal family tradition perishes. With the collapse of the tradition chaos overtakes the whole race.
41. adharmäbhibhavāt krsṇa pradusyanti kulaśtriyaḥ strīsu duștāsu vārșneya jāyate vamasamkarah
41. Such predominance of chaos leads to the corruption of women in the family. When the women are corrupted the whole society erodes.
42. samkaro narakāyaiva kulaghnānām kulasya ca patanti pitaro hy eșàm luptapịndodakakriyä $\grave{h}$
42. This erosion leads to hell for the family and those who destroy it Their ancestors end up in hell too, because the ancestral rites are discontinued. vamasaṃarakārakaih. utsädyante jātidharmä̀
43. doșair etaih kulaghnânām kuladharmāś caśaśvatāh
43. The crimes of those who destroy their kinsfolk cause promiscuity; They overturn the rules governing caste and the eternal family traditions.

One must focus on the expression eternal family tradition in the last line to grasp the significance of how the translation has transcreated the universe of discourse. The Sanskrit words used for 'eternal family traditions' is śấsvata-kula-dharma - to simplify the form. The word śăśsata is synonymous with sanātana in Sanskrit. We have here then the philosophically odd situation in which the destruction of what is eternal is being suggested! The difficulty disappears if it is realized that the word sanãtana or 'śâsvata can also mean 'ancient' or better still 'immemorial'. What Arjuna is perturbed about here is the destruction of ancient or immemorial traditions - doubtless a legitimate fear in troubled times. In fact "the words sanātanadharma are used in the sense of ancient practice no longer prevalent" and in "the sense of "duty recognized long ago' in the Rāmāyana" (Kane V-II: 1629).

Now to concentrate on the word dharma itself. Here again a verse from the Bhagavadgīta $\vec{a}$ serves to illustrate the issue of translational semantics. It somehow seems appropriate to select the verse from the Bhagavadgit $\bar{a}$, as it is perhaps the single most frequently translated (Callewaert 1983: 249) and most frequently read (Basham 1989: 94) Hindu text in English. The verse in question also happens to be one which is regarded as the ultimate utterance (caramaśloka) of the text in some sects of Hinduism. It is the 66th verse of the last chapter of the Gīta and is reproduced below in text and translation (Bolle: 210-211): 
66. sarvadharmān parityajya mäm ekam śaranam vraja aham tvā sarvapapebhyo mokṣayiṣyāmi mä śucah
66. Passing beyond appearances, come for refuge to me alone. I shall set you free from evil. Do not be anxious.

The first line contains the expression sarvadharmān. Arjuna, the friend and devotee of Krṣna, is being exhorted to seek refuge in Kṛ̣na alone, having abandoned all dharmas! Ordinarily dharma is something meant to be followed rather than forsaken - so even for the tradition itself there is a conundrum involved here. The following rather extended but useful comment by Kees Bolle helps to set up the problematic (Bolle: 243):

The most disputed and difficult passage in which the term dharma occurs in the Bhagavadgita is 18.66. This is where Krṣna invites his pupil to leave or abandon all dharmas and to go for refuge to him alone. There is no doubt that the context wants us to understand that we are at the high point of the Gitā's teachings. In the following verses Kṛșna speaks about their secret nature and about the 'highest mystery' for his worshippers. How should we interpret 'all dharmas' that are to be abandoned here? It is possible to think again of duties (Edgerton and others). It is also possible to broaden our understanding a bit and think of all rules (règles, says Sénart). In either case, the implication is that commonly accepted coherences and norms of life are somehow transcended.

Kees Bolle then goes on to say (243-244):

At first sight, the old glosses by Śankara and Rāmānuja seem to add to the confusion. Śanikara claims that one should abandon both dharma and its opposite, adharma. Thus he seems to understand the word dharma in the text as something exceedingly flexible: it refers to the right duty as well as the mistaken duty. Rãmānuja's interpretation is more complex, but his view is principally - and predictably - that all religious forms and acts (of karman, jñana, and bhakti) leading to God should be continued. He also states that nonessential rites, and, of course, obsessions with the results and agency of religious acts should be abandoned. Sankara and Rämānuja are obviously not in agreement, but both come out with interpretations assigning a wide spectrum of meaning to the dharmas in the text - too wide to be comfortably covered by any of our terms: duty, law, and the rest.

Bolle's own resolution of the problem, however, virtually leaves one breathless. He thinks that the word here carries the Buddhist connotation of "coherences present in the phenomenal world" (244) and translates it as appearances. In doing so, he outdoes even Śankara, the Hindu savant who is often accused of imposing his own Advaitic or monistic interpretation on the text. According to Sankara the "things of the world though not ultimately real, are yet of a certain order of reality, they are appearances..." (Hiriyanna: 156). Yet even Sańkara does not translate the word dharmas as appearances, though familiar with Buddhist thought. Neither the ancient cultural context nor the present day crosscultural context is really of much help here. It is the textual context which is primary. I believe W. D. P. Hill is right in suggesting that those "commentators who see in dharma a sectarian reference" - including the Buddhist - "are ignoring the context of the passage" which seems to suggest the sense of "all kinds of work" - or duties - "and perhaps especially the caste duty with which Arjuna is concerned" (Hill 1969: 212).

We have now surveyed the translations of the term dharma at both its more general and specific level and seen how it is the meaning of the word rather than the word itself which holds the key to conveying the intended sense. The deconstructionists may join issue when it is claimed that the meaning of a word is determined by the intention of the speaker or the text. But at least in the field of translation of religious texts this is still an honourable view of which the Sūfi statement that "no understanding of the Holy Book is possible until it is actually revealed to the believer as it was revealed to the Prophet" 
(Murty: 285) remain the paradigmatic utterance. But then the Prophet was a transmitter, not a translator!

The task of the translation is necessary, but treacherous and the delicacy of this enterprise has often been conveyed by employing marital and romantic tropes. It may be said that the basis of attraction in the matter of both translation and marriage is the same for both the parties - it makes a life of deception inevitable for both! On a more romantic note it has been suggested that a translation is like a lovely lady, "lovely when she is faithful and unfaithful when she is lovely". But I prefer the metaphor that the burdens of translation, like the bonds of matrimony, are so heavy that it takes two - and sometimes three - to carry them! It is the duty of the translator to try to remain true to both the author and the reader as long as one can!

\section{REFERENCES}

BASHAM, A. L. (1959): The Wonder that Was India, New York, Grove Press.

BASHAM, A. L. (1958): "Theraväda Buddhism", in W. Theodore de Bary et al., Sources of Indian Tradition, New York, Columbia University Press.

BASHAM, A. L. (1989): The Origins and Development of Classical Hinduism, Kenneth G. Zysk (Ed.), Boston, Beacon Press.

BOLLE, Kees (1979): The Bhagavadgitā: A New Translation, Berkeley, University of California Press.

CALLEWAERT, Winand M. and Hemraj SHILANAND (1983): Bhagavadgĩtānuvāda: A Study in Transcultural Translation, Ranchi, Satya Bharati Publication.

CHATURVEDI, Badrinath (1990): "Dharma: The Individual and World Order", India International Centre Quarterly, Monsoon, 27-38.

HICK, John H. (1983): Philosophy of Religion, Third Edition, Englewood Cliffs, New Jersey, Prentice Hall. HILL, W. D. P. (1969): The Bhagavadgitä. Second Edition, Oxford University Press.

HIRIYANNA, M. (1948): The Essentials of Indian Philosophy, London, George Allen and Unwin.

KLOSTERMAIER, Klaus K. (1989): A Survey of Hinduism, Albany, State University of New York Press.

MAHADEVAN, T. M. P. (1937): "The Religiophilosophic Culture of India", in Haridas Bhattacharyya (Ed.), The Cultural Heritage of India, Vol. I, Calcutta, The Ramakrishna Mission Institute of Calcutta.

MAHADEVAN, T. M. P. (1971): Outlines of Hinduism, Bombay, Chetana.

MONIER-WILLIAMS, Monier (1891): Brăhmanism and Hinduism: or Religious Thought and Life in India as Based on the Veda and Other Sacred Books of the Hindus, London, John Murray.

MURTY, Satchidananda (1974): Revelation and Reason in Advaita Vedānta, Delhi, Motilal Banarsidass.

RADHAKRISHNAN, S. (1927): The Hindu View of Life, New York, Macmillan.

SMITH, Wilfred Cantwell (1963): The Meaning and End of Religion, New York, The Macmillan Company.

WALKER, Benjamin (1968): The Hindu World: an Encyclopedic Survey of Hinduism, II vols., New York, Frederick A. Praeger.

WILKINS, W. J. (1887): Modern Hinduism being an Account of the Religion and Life of the Hindus in Northern India, Calcutta, Thackner, Spink and Co. 